\title{
The Essence of Civil Society in Democracy
}

\author{
Saverinus Rio Jama \\ Pancasila and Citizenship Education Study Programs, Faculty Of Social Science \\ Universitas Negeri Malang, Semarang Street No 5, Malang, Indonesia \\ saverinusriojama@gmail.com
}

\begin{abstract}
Currently, the role of civil society tends to be stronger in counterbalancing state domination through a democratic system. The state's efforts to create a responsive civil society, namely continuing to instill democratic values based on Pancasila and the 1945 Constitution of the Republic of Indonesia. This article aims to examine the prospects for civil society in a democracy. This research uses a qualitative descriptive approach with the type of literature study with data sources in the form of journals, books, and working papers that are relevant to deductive, inductive, and comparative data analysis. The results show that civil society in the current democracy frame is seen as being able to balance the dominance of the state in policymaking. However, if we look at it, on the other hand, it is quite difficult for us to argue with the actors and political elites, businessmen, and other elites who are not directly involved with the government so that their role is able to determine the wheels of policy as their output even though it may reduce the legitimacy of the state. This is also when we elaborate with the theory of democracy according to Robeth Dahl, where basically modern democracy today is strongly influenced by the capitalization and liberalization of the market economy sector which has a significant double impact on the prospect of a complete democracy.
\end{abstract}

Keywords: Civil Society, democracy.

\begin{abstract}
Abstrak. Saat ini peran masyarakat sipil cenderung lebih kuat dalam mengimbangi dominasi negara melalui sistem demokrasi. Upaya negara mewujudkan masyarakat sipil yang responsif yaitu terus menanamkan nilai demokratis berdasarkan pancasila dan UUD NRI Tahun 1945. Artikel ini bertujuan untuk mengulas tentang prospek masyarakat sipil dalam demokrasi. Penelitian ini menggunakan pendekatan deskriptif kualitatif dengan jenis studi kepustakaan dengan sumber data berupa jurnal, buku-buku, dan working paper yang relevan dengan analisis data deduktif, induktif, dan komparatif. Hasil penelitian menunjukkan bahwa masyarakat sipil dalam bingkai demokrasi saat ini dipandang mampu mengimbangin dominasi negara dalam penentuan kebijakan. Namun apabila kita cermati dilain sisi bahwa cukup sulit kita bantah terkait para aktor dan elit politik, pengusaha, dan elit yang lainya secara tidak lansung terlibat dengan pemerintah hingga peran mereka mampu menentukan roda kebijakan sebagai outputnya meski kemungkinan mengurangi legitimasi negara. Hal ini juga apabila kita elaborasi dengan teori deokrasi menurut Robeth Dahl dimana pada dasarnya demokrasi modern saat ini memang kuat dipengaruhi oleh kapitalisasi dan liberalisasi sektor ekonomi pasar yang signifikan berdampak ganda pada prospek demokrasi yang utuh.
\end{abstract}

Kata Kunci: Masyarakat Sipil, demokrasi 


\section{INTRODUCTION}

During the last few years, many social movements calling for more direct citizen participation in the political process have emerged in several countries around the world (Correa-Lopera, 2019). The results show that the role of direct democracy is better if the first is that the majority of voters are pragmatic, and the second is that the society is ideologically polarized. Direct democracy is a collective instrument of choice in Indonesia, where the majority of voters have the same ideological bias (Zaini, 2019). There are three basic patterns of democracy related to political orientation, namely, 1) oriented to ignore minority rights and interests, 2) conventional, namely having a narrow understanding of civil liberties, 3) liberal, namely supporting minority rights and civil liberties. Of these, the pattern of liberal views is considered to be the most unstable over time and its stability when linked to institutional trust and public participation (Šerek \& Lomičová, 2020).

In the literature when considering the features of political structure, democracy produces its strongest positive impact in the long run (Elbahnasawy, 2020). Policymakers generally believe that civic intervention improves the performance of democracy. Positive things of democracy in enhancing a responsive political system are the basis for civil society intervention (John \& Sjoberg, 2020). People's attitudes in democracy as reflected in citizens' knowledge and electoral behaviour certainly affect their political participation (Stutzer et al., 2019). A democratic process that produces political information can organize civil society to discuss social issues and political issues that can strengthen democratic participation.

The quality of democracy in general can be viewed objectively from an economic perspective in influencing people's satisfaction with the quality of democracy itself (Christmann, 2018). The results show that the parameters in the evaluation of the democratic process can also be measured through public policy and administration. Finally, democratic claims such as transparency and accountability are not only features of the political system as a whole but have also entered into the way public organizations are managed (Sager, 2018). In fact, society today believes that the institutional contribution of public institutions through regulations is an effective decisionmaking process that is transparent in today's democracy (Gallier, 2020).

The strengthening of national democracy in a country depends on the success of democracy locally. To achieve this, the most important aspects, namely political behaviour and a way of life, require the support of each individual in society as the owner of sovereignty, (Rahmatulloh, 2013). Currently, civil society and the market depend on each other as the connectivity of civil society in carrying out their civilian duties according to the circumstances. Thus, of course, it has a 
difference when compared to the military, which must be obeyed (civil disobedience) (Sandy, 2018). The aspect of democracy in strengthening efforts emphasizes various important aspects, of course, such as knowledge, behaviour, and the role of policies in various aspects of life in a state.

This article aims to explore the nature of civil society in terms of democracy in Indonesia. This article focuses on the form, application and efforts to become a democratic society that is always politically involved and participating as the prospect of deliberative democracy. Strengthening civil society is a basic concept of democracy guaranteed through the 1945 Constitution of the Republic of Indonesia. The prospect of strengthening civil society is to form good, active and politically responsible citizens as part of the actualization of human rights (HAM).

\section{RESEARCH METHODS}

This research used a descriptive qualitative approach with the type of literature study. This library research was used to collect in-depth information and data through literature, books, notes, magazines, research articles and references to previous research results (Norman K. Densin \& Lincoln, 2009). Sources of data in this study were primary data sources and secondary data sources. Primary data sources were the main data sources that researchers collected directly from the research object, namely, books, news, and articles. Secondary data was additional data to support primary data such as articles, books, and news to support concepts and theoretical studies on primary data. This study used data collection techniques which consisted of editing, namely the process of checking raw data, organizing, namely organizing the data from the results of editing, and finding, namely the researcher carrying out further analysis of the data from the results of the organization based on the predetermined theoretical method to find conclusions from the formulation of the problem. lifted up. The data analysis used was deductive, inductive, and comparative analysis, namely comparing the results of the analysis with relevant theories (Yaniawati, 2020).

\section{DISCUSSION}

The research results show that a state is a form of civil society as a result of the proletarian revolution. As it develops, however, state power is still manifested by hegemony itself (Raharjo, 2016). Even though the hegemony role of the state is quite strong, what is one form of civilian power to counterbalance it is the strong religious ideology which strongly opposes any aspect 
that is considered unbalanced or fair. The results of this research are also based on several literacy reviews showing that the civil society movement is essentially seen as a form of resistance to the country's strong hegemony, either through the military apparatus, the bureaucracy or through its technocrats. Another finding of this research is that the current state hegemony is a problem related to power, economy, social, culture, religion, to the problem of the majority with the minority ((Duija, 2017). So far the chaos in the current context of civil society sees that The political construction of the state is too dominant and extends to the issue of the privacy of its citizens. Thus, if we review the emergence of a form of civil society challenge against state domination, which often goes through demonstrations and even affiliation through certain ideologies. this is significant by the middle-class movement, non-governmental organizations (NGOs), intellectual movements, as well as the mass media, and other movements. Furthermore, the issue of civil society and democracy, if we examine it based on the theory of civic engagement from Donatela Dela Porta (2012: 254), explains that there is a causal relationship between social movements carried out by civil society and the upholding of democracy. The three concepts offered from this theory include liberalization, transition, and consolidation (Putri, 2018). Liberalization is marked by the emergence of a sense of volunteerism in the form of mass mobilization to protest against the regime. Transition is a civilian movement that was initiated because of the pressure, especially on the human rights aspect, and consolidation is the last process to create a new regime in a complete democracy. These three aspects are the specifics of the civil movement regarding the mode of upholding complete democratization.

\section{Civil Society}

We can review the beginning of the awakening of Indonesian civil society from historical studies where the milestones of civil society's struggle against colonial nations such as the Dutch, British, Portuguese, Spanish and Japanese. The rise of Indonesian civil society is indicated by three forms of resistance, namely, the resistance of peasants in Java and Sumatra in the 19th century to the 20th century, then demonstrations and labour strike to demand a minimum wage, and the struggle of intellectual youth in expressing the spirit of nationalism, freedom. politics, and fighting for massive justice in the 90s. This series of components aimed to oppose the domination and manipulation designed by the colonial state.

Unlike the previous era, the resurrection of civil society today is essentially moving based on a concept of rationality that is different from the revival of civil society in the past, which was based on acts of domination, manipulation, and hegemony. The 
constitutional juridical basis for civil society participation is stated in Article 28 of the 1945 Constitution of the Republic of Indonesia which states that "freedom of association and assembly and expressing good oral thoughts and so on is stipulated by a law". Furthermore, this explanation from the aspect of internalization of civil rights can be reviewed based on the study of human rights as stated in the 1945 Constitution of the Republic of Indonesia in article $28 \mathrm{c}$ paragraph 2 , which states that "every individual has the right to advance himself by fighting for his rights acutely for the development of society, nation and society. his country ". Guarantee of political freedom and aspects of the actualization of human rights are the legality of civil society in democracy (Cahyono, 2017).

This classification of the rise of civil society can also be manifested in several forms of social movements. The First, namely in the form of symbolic resistance with indicators such as direct action aimed at controlling the domination of the state. Second, namely pragmatic resistance which is seen as a form of direct reaction to ongoing policies such as economy, politics, and social, involving community organizations, political parties, and even students. The third form is in the form of symbolic resistance which is pragmatism in which this form is carried out by action, either directly or indirectly, to reduce state control of certain actions in society as a representation of a balanced sociopolitical life.

As for the context of civil society, if we look at it based on the views of a sociologist named Ernest Geller, who argues that civil society is an actor outside the government who has the main function of controlling the government. In this case, civil society is a predictor of order and prosperity with the aim that government domination and manipulation is minimized as much as possible to sustain the sovereignty of the people and the state (Parmudi, 2017). On the one side, civil society also participates intending to form joint public policies in the implementation of the state. Thus, the state and civil society collaborate in various aspects as a form of actualization of the values contained in the current constitution.

The relationship between civil society and the state is a form of association that is voluntary, both individually and collectively. The relationship between the two is independent in order to create responsive legal legality, so it is hoped that all components of both civil society itself and the government as policy actors have access through the public space in an accountable, open and responsive manner. The concept of accountability, openness and responsiveness can be assumed that civil society can act through the individuals it represents, such as The Houses Of Representatives of the Republic of Indonesia (DPR RI), The Regional 
Representative Council (Dpd), Even Law Enforcers Or Judges To Be Able To Prevent Theft Of Public Resources. Held By A Group Of Oligarchic Elites. However, It Turns Out That The Facts In The Field Show That The Represented Groups Tend To Behave Opportunistically And Do Not Act Accountably (Wahyunengseh, 2018). This Condition Is The Paradox Between Civil Society And The Government Today.

The current dynamics between the rises of civil society to control the domination of the state tend to be more symmetrical. If we relate it to the integralistic state theory conceptualized by Soepomo about organic community unity by prioritizing public interests over personal or individual interests. From this integralistic state state theory, it is manifested that in essence the government or the state must guarantee harmony because elements of society are seen as a complete unity. The dream is between elements of society and the government in power by promoting a harmonious balance (Arrobi, 2019). If one of the elements is stronger to dominate, then one day there will be vertical conflicts and it will cause divisions, which will certainly affect the integration of the country itself.

The presence of civil society is strongly influenced by the influence of liberalism and democracy, which are considered capable of ensuring participation in the public sphere. Civil society, which had previously handed over the legitimacy of its rights to the state, has the aim of ensuring that the state ensures its existence and capacity in various spheres. The role of civil society as part of liberal democracy certainly provides power to the state which enables the public to be able to be actively involved in responding to any existing policies. This is reinforced by the viewpoint of Tocqueville (1982: 3) in Seftyono, which explains that civil society is a democratic education that ultimately forms a stronger and more complete democracy (Seftyono, 2019). As part of this form of political participation from civil society, we can review the extent to which they can provide ideas, criticism and evaluation, in various fields of state policy. This transformation can be said to be a form of strengthening civil society against the beauty of the democratic process.

Furthermore, if we examine the experiences of other countries such as Latin America, Eastern Europe and Southern Europe, we should learn from the fact that the existence and participation of civil society are very instrumental in boosting the authoritarian power of the government. From this, it can also be understood that the essence of civil society is not only a forum for joining various associations, but more than that what is more urgent is the quality of civilians who can accept various kinds of political views, social behaviour, and are willing to be voluntarily 
involved in assisting the state in implementing public decisions.

We can refer to the constituent civil power in creating a responsive and accountable new era in legal democracy in Indonesia through the direct popular checker model. This is seen as a form of author's agreement when linked to Huberman's' ideas of deliberative democracy theory. In this study, civil society can become a pillar in charge of overseeing the running of the ongoing government. The constellation of civil society in this deliberative democratic order provides options for political goals that will be enforced through responsive legal policies.

As a broad illustration, the involvement of civil society certainly yearns for the realization of government and the fulfillment of sovereignty. This conception is based on the meaning that deliberative democracy can provide space for the growth of the principle of individual existence in carrying out maximum civic duties. With that, the creation of deliberative democracy can indirectly be improved and maintained. Although in the actualization and application of democracy, civil society has different features. This background is also inseparable from the aspects of the country's history, culture, ideology, and the targets to be achieved. Deliberative democracy is reflected in the aspects of feelings as well as behavior as the progress of democratic activities in the political system (Paristiyanti Nurwadani, 2016).

\section{Indonesian Democracy}

The assurance of human rights in democracy in the form of Indonesian constitutional practices is manifested in a system in accordance with the will of the state as stated in the fourth paragraph of the 1945 State Law of the Republic of Indonesia, namely people's sovereignty based on Pancasila. The existence of Pancasila in Indonesia can be a parameter in the implementation of democracy and human rights (Armiwulan, 2019). The realization of human rights is manifested in political party institutions in accordance with the predicate of democracy that comes from the people, by the people, and for the people which is further projected through institutional mechanisms such as political parties (Agun Gunandjar Sudarsa, 2008)

The main characteristic of democracy as an absolute requirement in the form of government by all citizens who meet the requirements as citizens (Paristiyanti Nurwadani, 2016). Democracy can be divided into two studies, namely formal democracy and substantive democracy. Formal democracy refers to democracy which is closely related to the government system and various state practices. Meanwhile, substantive democracy refers to how the democratic process is applied in society. 
Some experts have actually described various forms of the concept of democracy with their respective theories as a picture of our study in examining the nature of democracy itself. First, the concept of the theory of protective democracy popularized by Jeremy Betham and James Mill, where they explain that the power of a regular market economy is a separate concept with the aim of advancing market interests, on the other hand, protecting tyrants. Second, namely development democracy where this conception assesses that humans are possessive individuals or creatures capable of developing the power to carry out state activities. Third, namely the concept of equilibrium democracy theory or pluralist democracy proposed by Joseph Schumpeter where according to his view that intensive rational participation is seen as a function of democracy itself. Fourth, namely participatory democracy proposed by Machperson, that it turns out that every individual will not be able to achieve democratic participation without prior changes such as social imbalances and social awareness. Some of these theoretical studies do have a causal relationship in shaping individuals and communities in an effective democratization process.

The democratization process indicates that there is a public space that becomes an arena for the implementation of both individual and collective rights of civil society in a democracy. We can make further studies from Hubermans as a knife of analysis that in fact, the public space has several characteristics, namely, a focus on rational and critical issues, equality for all participants so that they continue to develop themselves to always be involved until these individuals participate and are supported by basic freedom such as speech, expression, and publication of any issues related to the public interest. This competence, both individually and in groups as citizens, certainly has the opportunity to participate or be fully involved for the state as a basic attitude of the integration of civil rights (Rahmandani \& Samsuri, 2019).

Ideally, the rationality of power is in the form of space for critical public discussion. In principle, civil society consists of private individuals, not as officials, state apparatus, or businessmen, but in principle, they are the ones who form the space, namely the public space. This context is what makes these private individuals public because apart from that they certainly have the guarantee to assemble and associate freely (Bahruddin, 2020).

Other studies related to democracy can also be viewed from the viewpoint of Robeth Dahl who said that the biggest challenge to high-quality democracy in the era of modern society today is the aspect of unequal political distribution. Ideally, people have the same competence in determining important policies implemented by their countries. However, these ideals are quite difficult to achieve, especially in an economic community that 
prioritizes a capitalist market economy. Whether it's a developed country like America or a developing country like Indonesia today. According to Dahl in On Democracy (1998), it is explained that modern democracy is currently strongly influenced by the existence of a capitalist market. The quality of democracy today requires serious efforts from various groups, especially in areas that are considered very strategic and potential (Thomas B. Pepinsky, R William Liddle, 2012).

Although several critical theoretical arguments from some of these experts provide detailed knowledge regarding how true democracy is in accommodating the interests of civil society, in fact, the existence of civil society is only considered to be capable of complaining about moral, economic and sociopolitical injustice. In fact, it is quite difficult for us to argue that actors and political elites, businessmen, and other elites are not directly involved with the government so that they determine the wheels of policy even though it may have negative effects such as a lack of state legitimacy. Concretely from Dahl's point of view, it is very clear that it makes us realize that in fact, it is the capitalist economy and market liberalization that have a significant double impact on the prospects for complete democracy. Various forms of policies, such as those in the social, economic, and even political spheres, have now succeeded in deceiving the essence of democracy, which is seen only as of the right of civil society. This has now become a real challenge for the Indonesian state.

Democracy as a political system leads to a fundamental paradox of participation because on the one hand democracy is a political system that empowers all citizens to participate in their own government. As has been conceptualized by Schumpeter (1974) that this minimalist conception of democracy does not require that groups or individuals participate in democratic elections either as voters or as candidates. Most democracy theorists say that the political system has ceased to be a democracy. But the challenge of potentially anti-democratic groups participating in democratic elections is not just a theoretical possibility. This is a practical concern that occupies pro-democracy activists, practitioners, and policy makers both now and in the future (Thomas B. Pepinsky, R William Liddle, 2012).

\section{CONCLUSION}

Liberalization, transition and consolidation are modes of democratization carried out by civil society to fight against the hegemonic regime of the state on various problems. As a form of strengthening in a democratic frame, we can understand it by placing civil society in it so that it is more active and massively involved through civil and political action. Based on the theory of democracy developed by Dahl and other 
experts, in essence, it is said that modern democracy today is very clearly dominated by certain elites through the liberal market capitalism system. Some forms of civil society awakening are manifested in several types of movements, be it social, symbolic resistance, pragmatic resistance and even in the form of pragmatic symbolic resistance. This is an indicator that it turns out that civil society as an actor outside the government has the power to balance the dominance of the state.

\section{REFERENCES}

[1] Agun Gunandjar Sudarsa. (2008). Sistem multipartai di indonesia. Jurnal Peraturan, 112. https://doi.org/http://ejurnal.peraturan.go.id/index.php/jli/article/vi ewFile/285/172

[2] Armiwulan, H. (2019). Catatan Kritis Sistem Hukum Dan Praktik Ketatanegaraan Republik Indonesia Di Era Reformasi. University of Surabaya Repository, 2. https://doi.org/http://repository.ubaya.ac.id/3 $7329 /$

[3] Arrobi, M. Z. (2019). Pancasila, Negara, Dan Masyarakat Sipil: Suatu Tinjauan SosioHistoris. Jurnal Majelis Media Aspirasi Konstitusi, 11(November), 111-119. https://d1wqtxts1xzle7.cloudfront.net/63

[4] Bachtiar, F. R. (2014). Pemilu Indonesia: kiblat negara demokrasi dari berbagai refresentasi. JPP (Jurnal Politik Profetik), 2(1). $\quad$ https://doi.org/http://journal.uinalauddin.ac.id/index.php/jpp/article/view/817

[5] Bahruddin, M. (2020). Partisipasi publik: isu agama dan politik dalam konteks demokrasi di media online. Https://Www.Researchgate.Net/Publication/ 338456545. https://www.researchgate.net/

[6] Cahyono, M. (2017). Panduan Pemasyarakatan UUD NRI Tahun 1945 Dan Ketetaoan MPR Republik Indonesia. In Sekretariat Jenderal MPR RI (Edisi Revi, pp.
114-137). Sekretariat Jenderal MPR RI.

[7] Christmann, P. (2018). Economic performance, quality of democracy and satisfaction with democracy. Electoral Studies, 53, 79-89. https://doi.org/10.1016/j.electstud.2018.04.0 04

[8] Correa-Lopera, G. (2019). Demand of direct democracy. European Journal of Political Economy, 60(May). https://doi.org/10.1016/j.ejpoleco.2019.08.00

[9] Duija, I. N. (2017). Masyarakat Hindu Dalam Politik NKRI Menuju Masyarakat Sipil. 1(1). http://jurnal.stahnmpukuturan.ac.id/index.ph $\mathrm{p} /$ Purwadita/article/viewFile/4/3

[10] Dwipayana, A. A. (2009). Demokrasi Biaya Tinggi Dimensi Ekonomi dalam Proses Demokrasi Elektoral di Indonesia Pasca Orde Baru. Jurnal Ilmu Sosial Dan Ilmu Politik, 12(3), 257-390. https://doi.org/https://journal.ugm.ac.id/index .php/jsp/article/view/10971

[11] Elbahnasawy, N. G. (2020). Democracy, political instability, and government tax effort in hydrocarbon-dependent countries. Resources Policy, 65(November 2019), 101530. https://doi.org/10.1016/j.resourpol.2019.1015 30

[12] Gallier, C. (2020). Democracy and compliance in public goods games. European Economic Review, 121, 103346. https://doi.org/10.1016/j.euroecorev.2019.10 3346

[13] John, P., \& Sjoberg, F. M. (2020). Partisan responses to democracy promotion Estimating the causal effect of a civic information portal. World Development, 130, 104914.

https://doi.org/10.1016/j.worlddev.2020.1049 14

[14] Norman K. Densin, \& Lincoln, Y. S. (2009). Handbook Of Qualitative Research. In Dariyatno, B. samsul Fata, Abi, \& J. Rinaldi (Eds.), Pustaka Belajar (Edisi Kedu). https://doi.org/Pustakapelajar@yahoo.com

[15] Paristiyanti Nurwadani, D. (2016). 
Pendidikan kewarganegaraan di perguruan tinggi. In I. Ahmad (Ed.), Thema publishing (cetakan pe). Direktorat Jenderal Pembelajaran dan Kemahasiswaan Kementerian Riset Teknologi dan Pendidikan TInggi.

[16] Parmudi, M. (2017). Kebangkitan Civil Society di Indonesia. At-Taqaddum, 7(2), 295-310.

https://doi.org/http://journal.walisongo.ac.id/i ndex.php/attaqaddum/article/viewFile/1208/9 51

[17] Prasetyoningsih, N. (2014). Dampak Pemilihan Umum Serentak bagi Pembangunan Demokrasi Indonesia. Jurnal Media Hukum, 21(2), 241-263. https://doi.org/https://journal.umy.ac.id/index .php/jmh/article/view/1190

[18] Putri, Y. I. (2018). Kontribusi Masyarakat Sipil Domestik dan Transnasional Dalam Memperjuangkan LGBT di Afrika Selatan 1991-2006. Jurnal Analisis Hubungan Internasional, $\quad 7(1), \quad 251-265$. http://journal.unair.ac.id/downloadfullpapers-jahi9e9c565d20full.pdf

[19] Raharjo, M. D. (2016). Demokrasi, Agama dan masyarakat Madani. Unisia, 22(39), 2533. https://doi.org/10.20885/unisia.vol22.iss39.ar $\mathrm{t} 3$

[20] Rahmandani, F., \& Samsuri. (2019). Hak Dan Kewajiban Sebagai Dasar Nilai Intrinsik Warga Negara Dalam Membentuk Masyarakat Sipil. Fikri: Jurnal Kajian Agama, Sosial Dan Budaya, 4(1), 113-128. https://doi.org/10.25217/jf.v4i1.426

[21] Rahmatulloh. (2013). Wajah Demokrasi Jakarta Dalam Potret Indeks Demokrasi Indonesia (IDI). Journal of Chemical Information and Modeling, 53(9), 16891699.

https://doi.org/10.1017/CBO9781107415324. 004

[22] Sager, F. (2018). Policy evaluation and democracy: Do they fit? Evaluation and Program Planning, 69, 125-129. https://doi.org/10.1016/j.evalprogplan.2017.0 8.004
[23] Sandy, T. R. (2018). Menurunnya Kebebasan Berserikat Dan Berkumpul Pada Indeks Demokrasi Indonesia (IDI) Lampung 2016 (Vol. 2016) [Universitas Lampung]. https://doi.org/http://digilib.unila.ac.id/33222 /

[24] Seftyono, C. (2019). Membuka Ruang Teorisasi Kepemimpinan Masyarakat Sipil: Komunitas Epistemik Sains Terbuka. https://doi.org/https://osf.io/preprints/socarxi v/bzu9r/

[25] Šerek, J., \& Lomičová, L. (2020). Adolescents' transitions between different views on democracy: Examining individuallevel moderators. Journal of Applied Developmental Psychology, 66(March 2019), 101104. https://doi.org/10.1016/j.appdev.2019.10110 4

[26] Stutzer, A., Baltensperger, M., \& Meier, A. N. (2019). Overstrained citizens? The number of ballot propositions and the quality of the decision process in direct democracy. European Journal of Political Economy, 59(May), 483-500. https://doi.org/10.1016/j.ejpoleco.2019.05.00 8

[27] Thomas B. Pepinsky, R William Liddle, S. M. (2012). Indonesian Democracy and the Transformation of Political Islam Thomas. Journal of Chemical Information and Modeling, 53(9), 1689-1699. https://doi.org/10.1017/CBO9781107415324. 004

[28] Wahyunengseh, R. D. (2018). Forum Konsultasi Publik: Aktivis Masyarakat Sipil atau Klient Penguasa. Spirit Publik Jurnal Administrasi Publik, 12(2), 32-42. https://doi.org/https://jurnal.uns.ac.id/spiritpublik/article/view/26986

[29] Yaniawati, R. P. (2020). Penelitian Studi Kepustakaan (Issue April). https://www.google.com/search?q=Penelitian +Studi+Kepustakaan\&oq=Penelitian+Studi+ Kepustakaan\&aqs $=$ chrome..69i57j0j0i22i301 $6.1488 \mathrm{j} 0 \mathrm{j} 7 \&$ sourceid $=$ chrome $\& \mathrm{ie}=\mathrm{UTF}-8$

[30] Zaini, M. (2019). Kebijakan Pemberlakuan Politik Demokrasi dan Pengaruhnya Terhadap Kesejahteraan Sosial. Paradigma: Jurnal 
Filsafat, Sains, Teknologi, Dan Sosial Budaya, 25(1), 54-67. https://doi.org/10.33503/paradigma.v25i1.48 4 